\title{
Leadership in Self-organized Systems: Squaring the Circle or a New Kind of Responsibility?
}

\author{
Christoph Minnig ${ }^{1}$ and Peter Zaengl ${ }^{2 *}$ \\ ${ }^{1}$ School of Business \\ University of Applied Sciences and Arts \\ Northwestern Switzerland FHNW \\ ${ }^{2}$ School of Social Work \\ University of Applied Sciences and Arts \\ Northwestern Switzerland FHNW \\ *Corresponding author's email: Peter.zaengl [AT] fhnw.ch
}

\begin{abstract}
Current changes in society, in particularglobalization, demographic trends, and changes in the labour market, have far-reaching implications for how we live and work together. Common social problems, for instance, are becoming more complex and new problematic situations continually arise. With cuts in the social sector and increasing demands for efficiency and effectiveness, overall conditions are becoming worse. Faced with these developments, social security systems are increasingly pushed to the limit and are forced to redefine their areas of responsibility. In addition, we must take account the issue of crowding-out processes in the social sphere. Large, mostly internationally operating enterprises for example are increasingly receiving performance contracts from governments in the areas of elderly care or immigrant services. It is also apparent that social service organizations are overloaded and that their established structures and historically evolved market positions are eroding. In the current discussion, we have to find answers to at least two questions within the context of developing organizations:
\end{abstract}

1. How should we build organizations so that they are able to withstand or handle these challenges?

2. How can we define the role of leadership in these organizations?

First, we will discuss the concept of responsibility. We will then describe the different challenges that organizations face, particularly in the social sector. Based on Frederic Laloux's (2014) model of "Evolutionary Organizations," we will present a critical discussion of the possibilities for responsible leadership that are available to organizations in the social sector.

Keywords - self organization, responsible leadership, hierarchy and heterarchy, social economy

\section{THE CONCEPT OF RESPONSIB ILITY AND WHO IS RESPONSIB LE FOR WHAT}

For the sociologist Max Weber (1992), the responsibility of action is the most important criterion for its legitimacy. This requires a minimum of attitudes (ethics of thought) and a necessary degree of sense (responsibility ethics). As a result, responsibility has two sides, an individual and a social side. We are responsible for the development of our world, everyone on his or her own level. This is well illustrated by the United Nations (UN) development goals: the UN Millennium Development Goals (MDGs), which applied from 2000 to 2015, had already addressed ecology and equality. Their focus was on combating poverty and hunger, improving education and health for all. In general, they were successful in their implementation: the number of extremely poor people has been halved since the UN agenda was announced, despite China's economic boom. Child mortality fell sharply, and the number of children attending school, at least at the elementary level, increased (Rosling, 2018). In June 2013 in Rio, the UN therefore decided that sustainability targets should replace the MDGs (United Nations, 2015a). The new sustainable development goals (SDGs) are intended to combine an economically, socially and ecologically sustainable development and these goals where modified by the UN in the new Agenda until 2030 (United Nations, 2015b).

The implementation of the current 17 goals and 169 subgoals for a better world is voluntary. Each state is left to do what it wants to do in order to achieve its aims. In practice, this means that each state gets to decide which of the goals it prioritizes, whether it does anything at all, and which ones it neglects. Ultimately, reaching the targets succes sfully depends on whether the states and the private sector give enough money and truly pursue the development goals with commitment. The SDGs demand the assumption of responsibility at all levels. 
Enterprises, and above all their people, face nearly unsolvable tasks. They have to react to all sorts of trends and megatrends: for example, the consequences of globalization, the changes in the workforce and the demographics, the erosion of values, the new paradigms such as inclusion, and many more. These challenges do not only apply to so-called economic enterprises but social enterprises also face these increased competitive pressures.

In the so-called quasi-market of the social sector (see the theory of quasi-markets: Le Grand \& Bartlett, 1993 and Brandsen, 2004, and Trube \& Wohlfahrt, 2000 and Bode, 2005), large changes are obvious, as governments' expenditures on social services have been cut, and the competition has intensified. In addition, commercial suppliers have an increasing market share of the social sector, and quality and price are becoming the most important competitive factors (cf. detailed Zängl, 2015). These are some of the factors that necessitated changes in organizational processes, in reaction to social and market trends. For example:

- Companies and enterprises are now seen as learning systems;

- Services and products are more the result of cooperative activities and depend less on the activity of a single autonomous organization;

- Effectiveness and efficiency have become core elements of quality discussions;

- $\quad$ There is a recognized need for new, different and varied forms of leadership approaches;

- $\quad$ Lifelong learning for all professionals, including executives, is becoming recognized as a need and a standard; and

- Control activities are becoming increasingly focused on effects.

\section{CHALLENGES THAT MATTER IN A SOCIAL ECONOMY}

Responsible leadership in social-organizations faces the horns of at least three dilemmas:

- $\quad$ The challenges of its different mandates

- $\quad$ The double bind of rationality

- $\quad$ The antagonism between loose and tight coupling

The challenges of the different mandates

Social work, understood as a subsystem of modern society, deals with "scientifically well-founded certain social problems of functional differentiation" (Sommerfeld, 2003, p.11). The focus is on problems of inclusion and exclusion of persons or groups "who cannot cope with their social living conditions, who fail in their individual coping with life, who have only very limited participation in society and are threatened or affected by permanent social exclus ion" (Sommerfeld, 2003, p .11). This understanding of the task presupposes that the "objective" circumstances (living conditions), as well as the "subjective" framework (lived-in world), must be the focus of preventive and/or curative social work (Uebelhart $\&$ Zängl, 2012, p. 99). The design of care systems in the social environment of these people is the focus of political and social work interventions (see Schneider \& Minnig, 2011).

The tasks resulting from these claims are described in the definition of the International Federation of Social Workers as follows: "It promotes social change, problem solving in human relationships and empowerment and liberation of people to strengthen well-being. Based on theories on human behavior and social systems, social work takes place where people interact with their environment. The foundations of human right social justice are essential to social work "(see IFSW, 2012). As a result, professional and managerial staff are fully committed to their clientele, according to the triple mandate of social work (see Staub-Bernasconi, 1995), the state and its own code, which is based on the human rights treaty (https://www.un.org/en/universal-declaration-human-rights/index.html (downloaded on the 29. of March, 2019)). As a result, social work, whether public or private, cannot be satisfied with the provision of individual, is olated services, both in terms of territoriality and equal rights. As an advocate of its clientele, it must increasingly interfere with social and political decision-making processes. The social work agenda that has grown out of this finds it almost impossible to fulfil its own complex mandate, since there are extreme conflicts between the mandates. It is not always "good" for the client, and the client is not always "right" in regard to the social-state mandate. The provision of social aid can compete with social policy objectives. Examples include the unintended stabilizing effects of poor development due to social work in the form of training dependencies and misguidance, unwanted promotion of procurement criminality in the fight against individual addiction problems, or the stabilization of poverty constellations due to poor care. 
The human rights mandate, whose objective goal is social justice, is not in itself free of conflict. The question of social justice can be answered differently depending on the specific understanding of justice. As Uebelhart and Zängl point out, "what virtues are rewarded and what kind of life should be promoted by a human society. Cu rrently, we are more concerned about how the fruits of prosperity or the burdens of the economic crisis are to be distributed, and how to determine the fundamental rights of the citizens. In these areas, the majority of considerations are dominated by public welfare and individual freedom. Only what was previously defined as equitable is justified. "(Uebelhart \& Zängl, 2015) What is regarded as socially just is a process of negotiation and also a question of power.

What follows from the competing mandates of social work? It can be seen that the field of social work can be characterized in two ways: first, it is characterized by ambiguities in relation to objectives, and second, by uncertainty as to their effects. The multitude of purposes, interests and goals inevitably leads to an often unclear, and sometimes chaotic, culture of decision-making processes in social-economic organizations. Uncertainty regarding social work exists particularly in the attribution of the effects of social aid on human development and education processes (see "technology deficit"). This situation can be mitigated but cannot be eliminated, depending on the methods used: any other expectation of the "efficiency of methods is in the tendency to self-deception" (see Galuske, 2003, p. 60).

Ambiguity and uncertainty regarding the function and effects of social work lead to complex decision -making situations for responsible leadership in which categories are not right/wrong or true/false but can only be inappropriate/appropriate and reasonable/unreasonable, given the respective context of the decision. Additional or different information would not necessarily aid in these decisions; at most it would increase the ambiguity of the decision-making process (Boaz, et. al. (2010).

\section{The double bind of rationality}

Executives in social organizations are subject to high pressures when making decisions. Their decisions should be made as rationally as possible; that is reasonably, deliberately and purposefully, with consideration for the use of funds to achieve the goal. However, what is understood by a rational decision is subject to the specific rules of interpretation of each social worker group. Economic rationality primarily refers to the efficient and effective use of resources, political ration ality refers to the appropriate means of achieving power, and social rationality refers to achieving participation. Given this diversity of definitions, rationality is an unsuitable criterion for judging decisions, since these can be classified as "rig ht" or "wrong" depending on the point of view (see Schedler \& Rüegg-Stürm, 2013). This applies whether we understand rationality in Weber's (1992) sense, which differentiates between formal and material rationality; whether we favor Luhmann's (2000) point of view, who explains rationality in connection with legitimation by methods; whether we understand rationality as a synonym for reason (e.g., Habermas, 1985); or whether we understand it in a broader sense (e.g., Bourdieu, 1982). The point is that what is meant by rationality always remains ambiguous.

For social work professionals, this leads to a permanent negotiation process (individually, organizationally, and socially) regarding what factors or perspective requirements regarding rationality must be satisfied in each case. It is therefore important to distinguish carefully who makes what claims regarding rationality.

How this will be decided in the end depends on different dimensions. Personal preferences and value systems are just as important as organizational processes and power structures, or social conceptions of morality and justice. For example, various decision-making aids, such as the Structured Decision-Making Model (Department of Social Services of California) or the Stuttgart Child Protection Sheet (Kindler, 2008), can be seen as objective guidance and not as "autopilots" (Lätsch \& Jud, 2014, p. 25) that take decisions away from the professionals. Focusing on a specific rationality carries the risk of developing a so called "culprit culture" (cf. the study of Munro, 2005). Therefore, in the context of social work, during the elucidation of "tragic events," the focus is always on the person who made the "wrong decision." Factors that might have influenced their decision are not subject to investigation (see Munro, 2005, p. 382). The observation that a decision-making process always involves different actors, with their different requirements for rationality, is largely ignored.

This is accompanied by a dominance of procedural rationality, in the sense of Luhmann's legitimacy of procedure according to which social decisions are primarily oriented towards the structures of "positive law" (Luhmann, 1969). By means of reasoning, checklists, instructions and the like, a certain rationality in decisions is required in each case, which on the positive side, leads to high transparency in work performance and, at the same time, structurally maintains structureconservative, and/or inhibits innovation on the negative side. Feyerabend describes this in his criticism of rationalis $m$ as a "method of declining movements." Innovations, in the Feyerabendian understanding, "occur, not because one has adhered to reason, as it was in the abstractions already obtained, but because it was reasonable enough to proce ed in an unreas onable way." (Feyerabend, 1984) Without going into the detail of Feyerabend's supposed methodological anarchism that underlies this thesis, it is clear that what is rational can be understood using the same logic that is used in the construction of social 
problems (see deputy for many: Groenemeyer, 1999). Rationality is a concept that is highly plastic and contingent, and this is precisely why social work is difficult in practice. There is a conflict between the different mandates of social work: the dominance of a certain rationality on one hand, and the as sociated high-path dependence of social work on the other hand. Basically this means that from the perspective of the clientele, rationality is understood as the best possible (effective) a id for improving the living situation, and from the perspective of the social policy mandate, rationality is the effective and efficient organization of aid as a rational consideration (rationalization). The obligation of social work to promote human rights is in turn characterized by quite a different rationality (rationalism). This conflict between the rationalities cannot be solved, but it is important to identify the rationality that is dominant and therefore decisive.

The antagonism between loose and close coupling

Depending on historical development, different social work areas are concealed behind the demands of social work, with equally highly differentiated forms of organization. This raises the question of how social work should be organized to be successful. On one hand, the ans wer is to be found in the core area of social work (value orientation, theories, methods and coproduction); on the other hand, the provision and development of (organizational) framework conditions are central to the answer. In the social work profession, there is tension between the claim of high autonomy (cf Otto \& Ziegler, 2011) and ambiguous mandates, as stated in the mandate challenges above. Since social work always, or at least predominantly, takes place in the context of organizations, the question arises as to how they must be designed. In this regard, it is primarily the relationships between individuals, departments, environments, hierarchical levels, ideas, activities, and between intentions and actions (see Orton \& Weick 1990, p. 208) that are more or less loosely or closely linked. In this situation the coupling takes place by means of structures (decisions that are the bas is for further decisions) into memberships, hierarchie s and the purpose of an organization. Regarding the concept of loose coupling Wolff writes: "If systemelements are loosely coupled, there is interdependence between them. However, this is reduced to the extent that a certain independence and identity of the individual elements is preserved." (Wolff, 2010, p. 288) Workplaces in the social work field are characterized by ambiguity and uncertainty and tend to be loosely coupled organizations. "They are especially effective in constellations where it is necessary to reconcile incompatible expectations with an organization, or at least to prevent the actual operation being restricted too much by these contradictions. [...] Loose coupling is also helpful when dealing with complex, unpredictable and difficult-to-control environments." (Wolff, 2010, p. 294) On the other hand, legislative or payer requirements lead to expectations for detailed documentation and evaluations, etc. Many organizations are therefore more closely linked.

Social-worker rationality with its claim to autonomy, its conflicting objectives and with its uncertain cause-effect models, is opposed to the service providers' rationality (legislators and payers), with their requirements for efficient performance and transparency, as well as evaluations and controls. In consequence, numerou s rationality myths are formed in social-economy organizations primarily through mimetic processes.

Organizations apparently need both close and loose couplings of their respective organizational units, in the sense of an "organized anarchy" (Wolff 2010, pp. 300ff.). Organized anarchies with decision-making methods analogous to the garbage-can model, are organizations that are characterized by ambiguous situations, unclear cause-and-effect relationships, and changing participants in their decision-making processes. "From this point of view, an organization is a collection of decisions that look for problems, a collection of facts and feelings that look for decision -making situations in which they might emerge as a collection of solutions that look for facts and a group of decision-makers who are looking for work." (Cohen et al., 1990, p. 332) In addition, leadership plays an extremely important role in organized anarchies: "The time at which problems come to the table carefully, react sensitively to changes in interests and engagements on the part of those involved, reflect the status and power implications of electoral and decision-making situations, drop initiatives that are different from those originally remote problems, and recognize that their planning function is largely symbolic and primarily provides excuses for their influence, leaders in organized anarchy can keep their clear view and sometimes even modify the decisions made." (Scott, 1986, p. 363f.)

There is a need for a careful balance between the respective units (e.g., individuals, teams, departments, workgroups, work units, organizational branches, satellite organizations, etc.) and their interaction or coupling, closely or loosely. The handling of information forms the bridge between loosely and closely coupled units. A balanced mixture of loosely and closely coupled organizational units only works when information within an organization is targeted, so that the degree of coupling can be varied in a manner appropriate to the situation.

\section{THE POP CULTURE OF "NEW MANAGEMENT AND LEADERSHIP MODELS"}

In our view, the current way we run organizations has been stretched to its limit. One way to meet these challenging goals would be to abandon the traditional forms of organization. In this context two key developments can be seen: on the one hand, there are new organizational paradigms, such as self-organized management (Laloux, 2014), and on the other 
hand, there exists an uncertain desire for a so-called clean and responsible entrepreneurship.

Contemporary discourse about organizational models therefore makes reference to terms such as self-organization, agile leadership (e.g., Scherber \& Lang 2015), democratic enterprises (Sattelberger \& Welpe \& Boes, 2015), 'honorable businessman' (Beschorner \& Hajduk, 2011), reinventing organization (Laloux, 2014), the scrum principle (Sutherland, 2015), leading change (Kotter, 2011), lateral leadership (Kühl, 2016), accelerate (Kotter, 2014), holocracy (Robertson, 2016), Sociocraty 3.0 (Bockelbrink et.al, 2019) and so on.

Most of these "new" organizational models have among other aspects self-management in common. They operate effectively by reducing overhead and back offices on a large scale, with a system based on peer relationships, without the need for either classical hierarchies, consensus or extreme control(ing). However, these terms refer to more or less empiric al anecdotes, and form a part of pop culture in management literature: what is missing is a theoretical foundation on which to put the scripted models into practice. Some provisional theories include Frederic Laloux's publication entitled "Reinventing Organization" (2014) or Gary Hamel's (2011) "Let's Fire All the Managers.” In his book, Laloux describes ten organizations that have found new ways of abandoning traditional organizational structures, both in their formal organization and development, as well as in their development and business purpose (more customer orientation, etc.).

Laloux has distilled three essential elements from the organizations that he investigates, which are characteristic of evolutionary organizations:

1. Self-organization/self-management

2. Wholeness

3. Evolutionary purpose

\section{Self-organization/self-management}

In this case, management functions are given to individual employees and teams. Guidance and execution are no longer separate units; rather, they are connected. The powers of decision-making and design are given to individual persons to a high degree. Professionals can make almost all of the decisions in their field of activity by themselves and agree on topics that concern several people with the team, or with the affected persons or experts (see also Vermeer et. al. 2016).

Self-organization is characterized by the following:

- $\quad$ Self-management and responsibility, instead of external leadership;

- Self and group controlling; and

- Subsidiarity instead of centralism.

Decision-making power is shifted to the periphery or to the base. Decisions from above no longer exist; rather they are made from below (consent model, see Strauch et al. , 2018)), or on the spot, or in direct contact with customers. It is no longer the central office or management that determines the design of the workplace; it is the individual persons and teams who decide independently how they will divide their work and satisfy the needs of the customers. Personal decisions are also made by affected parties. Central services support the work, instead of structuring it or setting it up.

For Laloux, the core element of self-organization is the individual consultative decision. Decisions are decentralized to affected clients and are not made in the center or at the top of a hierarchy. Each person can then make any decision regardin $g$ her or his area of responsibility. They only have to ask for advice from all the persons concerned, as well as the experts, beforehand. They do not need to take the experts' opinion into account, but they need to at least listen and take it as well as possible. These 'consulted decisions' are often faster and based on more insights that those that go through the traditional processes of hierarchical decision finding.

\section{Wholeness}

Wholeness means that every employee with his or her idiosyncrasies (e.g., values and peculiarities) can contribute. According to Laloux, this leads to a high level of satisfaction with work, creates a trusting atmosphere in which there is constructive coexistence, and contributes to better customer satisfaction.

Regarding leadership in evolutionary organizations, Laloux states that on the one hand, these positive values and guidelines must be clearly visible and implemented within the organization (congruence and integrity); and that on the other hand, there is a need for specific measures so that these values can come to life, create relationships and room for 
dialogue, and provide periods of time during which employees can contribute to their own completeness.

\section{Evolutionary purpose}

Laloux assumes that every organization has its own purpose or meaning, an order for the world, a right to exist. This purpose of existence is more than the sum of the acting persons, the structure, or the culture of the organization. It manifests itself by an attentive listening and feeling instead of rational determination, and it gives the direction. The internal or external environment gives feedback as to the extent to which the organization is able to go in this direction. Flexible reaction replaces the widespread concept of "planning and control."

The company is seen as a living being that has a life of its own. It wants to be realized in the world in a certain sense. Fundamental for this view is the change of perspective regarding means and purpose (Fink et. al. (2018). The focus of evolutionary organizations is not profit growth, but the orientation towards the customer and their unmet needs. Financial success is not seen as the main goal, but as a result of shift of perspective.

\section{ROLE OF LEADERSHIP IN EVOLUTIONARY ORGANIZATIONST}

With increasing self-responsibility the roles and tasks of leadership change. Specifically, this includes:

- $\quad$ Trust and continuity with the outside, without further management tasks, which creates protection and trust in the mission within;

- Guardians of the evolutionary organization, i.e., ensuring that the new path is being followed;

- $\quad$ Creating a new role model for evolutionary behaviors. The task of leadership is to live this attitude, especially in decision-making: to trust rather than to control, and thus to be willing to hand over responsibility to others.

Critique of the evolutionary organizational model according to Laloux

Criticism 1: A lack of theoretical foundation

For theoretical basis, Laloux refers to the integral theory of Ken Wilber (2007) and the Spiral Dynamics (SD) of Don Beck and Chris Cowan (1996), which he partly links. Spiral Dynamics was developed by Don Beck and Chris Cowan on the basis of Clare Graves' research. In the 1950s, and 1970s, Clare Graves, using psychological tests, posited a theory of personality development. The SD model is highly doubtfulas a theoretical foundation for an organizational model, because it is an individual model of consciousness (see Butters, 2015). The SD model is empirically based on psychological investigations of individuals, and an application of the model to historical developments in organizational form is therefore at the very least doubtful. An empirical proof, in the sense of basic research, is missing. The model is characterized by an almost naive belief in progress, i.e., that a person as an individual or as a whole can move to something higher, whatever that may be. This desire is then transferred to a more or less advanced evolution to a higher state of consciousness and to a more complex form of organization.

Criticism 2: The data collection is unclear and possibly too thin

Laloux focuses on positive examples in his work. He rightly calls these "empirical anecdotes." This is of course legitimate in the sense of "best practices" selection, but it is by no means intended to form a theory (especially not in the sense that it can be falsified). However, what we are mis sing are all those organizations that follow these new self-organized approaches but that are not so successful or that are falling behind completely. It is also striking that Laloux cites only executives and founders. Whether these CEO self-descriptions correspond to the perceptions of the employees remains uncertain. Neither the employees nor the key players are given voice, and we do not know much about their feelings and thoughts.

Criticism 3: The paradox of an organized heterarchy (Reihlen, 2009)

On the one hand, Laloux describes examples of decentralized organizational models, in which managers have less formal authority. According to Laloux, this applies both to the development of strategies as well as to personnelplanning and development issues. Laloux's examples, on the other hand, strongly impress how much the implementation of heterarchic structures depends on strong personalities or even on a visionary leader. Self-organized systems, as Laloux 
describes them, originate from hierarchical environments and decisions. When the pioneers and innovators withdraw for whatever reason, an organization often falls back into its old patterns (e.g., FAVI). Self-organized systems obviously depend on special leaders or special personalities.

At the end of the day - the tasks for responsible leadership

Laloux's descriptions of organizations remain impressive, despite the criticism. Although they do not serve to form a theory, they show a path for new developments in organizations. Success fulleaders in organizations such as Jos de Bloc (Kreitzer, et. al. 2015) distance themselves from what traditional theory has to offer. Specifically, the examples show the requirements for a responsible leadership in self-organized systems. We shall briefly explain that this does not require the squaring of the circle, in which we represent four ideational types of leadership in self-organized systems. In general, leadership in self-organized systems is radically different from leadership in traditional organizations (Vermer \& Wenting. 2016). It must be contextual, interactive, structural, and cultural:

1. The separation between leaders and executives is renegotiated temporarily and functionally. This does not mean that these systems are in a state of a lack of leadership or anarchy. In this context, responsible leadership means that similarly to the ideas of "organized anarchy," trust in the stability and development capability of organizations must develop through processes of participation. Such a contextual approach has the task of designing adequate cultural and administrative framework conditions.

2. Interactional leadership refers to the direct influence and shaping of the exchange relations between the leaders. In self-organized systems, the degree of participation in the management interaction must be significantly higher than in traditional organizations. Leaders do not have enduring and superior power to impose decisions on other people's decisions.

3. Self-organized systems must create conditions that, depending on the structure of the tasks at hand, lead to differentiation of specific roles within the management system. Each member of the organization, within the framework of structural leadership, assumes the role of tasks and responsibilities that is best suited to his or her competences and abilities to make the best possible use of existing knowledge.

4. Values and norms are developed through cultural leadership, joint thought patterns, and shared stock of knowledge, and these enable a cooperative, as well as an innovative community. However, there is a question as to how such a culture can be created or altered by means of leadership.

Given this background, there are two main aspects to responsible leadership:

1. How cooperation is created; and

2. How decisions are made.

\section{Cooperation as a central task of responsible leadership}

Cooperation does not emerge easily; it must be consciously and purposefully developed to this end, the organizations and persons involved must, as a rule, shape and ensure a more or less comprehensive learning and development process (Minnig, 2019). This also means that cooperation usually results from negotiations and is characterized by open communication and participatory decision-making processes. In cooperative ventures, we are also forced to create structures that enable decisions that are differentiated and based on reflection, and still made promptly. Cooperation creates shared expectations, visions and goals. Formal and informal games and conflict rules, as well as formal and informal power structures, develop. This means that cooperation develops and establishes its own realities and tendencies towards increased autonomy, as well as a growing independence within cooperation.

For this reason, we have to ask ourselves again and again about the balance between the autonomy of the individual organizations and their involvement in cooperation. Cooperation always takes place in the host organization, and at the same time, often also in foreign bodies in the same organization. We must therefore ask ourselves whether and to what extent, cooperative forms are sustainable in the long term, and whether they should be resolved or more clearly structured and deepened through a broader grouping. Cooperation is rarely a stable structure, and is often subject to large and dramatic changes.

In any case, the responsible and key personnel, both in terms of operational and strategic issues, must have a jointly developed and established interactive organizational understanding and thus be increasingly capable and willing: 
- To think and act using cooperative approaches, as well as to develop learning and development processes beyond the institution;

- To actively, openly and objectively reflect on the links between the organization and the environment, and, if necessary, to work with cross-organizational process models;

- To reflect, initiate, build up, consolidate and dissolve relationships with important partners (individuals and institutions);

- To allow different hierarchical forms (hierarchy and heterarchy); that is, to solve problems on the levels at which they occur (Minnig and Bühler, 2004); and

Perhaps, as a matter of principle, to understand cooperation as a new possible option that must be developed further beyond their own traditional boundaries.

\section{Decision-making}

Real decisions in the organization, such as the organization of the structures and processes inside the organization, are the subject of subroutines that make the decisions repeatable and automate the decision-making process. In contrast to the theories of the "rational decision" (see Esser, 1990, pp. 23ff.), Luhmann (2000) and von Foerster et al. (1992) do not contribute to the individual decision-maker and his rationality, that is, as rationally as possible by objectively determinable decision-making, but rather conceive decisions as a "social event." A subsequent conception is the garbage-can model by Cohen, March and Olsen (1972, p. 1ff.). This model does not describe how make decisions in uncertain situations (rational or intuitive), but rather provides information about how decisions are actually made as a social event. According to linguistic science, this could also be understood as a "contextualization" of decisions (see Auer, 1986, p.22ff.). According to this logic, decisions based on the garbage-can model essentially depend on four factors, which are relatively independent from each other:

1. Problems that currently have to be addressed in the organization;

2. Solutions that are currently available and looking for problems that they can be applied to;

3. Organization members; and

4. Decision-making (Cohen / March / Olsen 1972, p. 33).

Decisions are made when these four streams flow together. In otherwords, if the right people meet at the right time and find solutions to a particular problem, then a decision (though uncertain) can be made. At first sight, this conception of decision-making seems trivial, but in practical implementation, it proves challenging because decision-making situations are always characterized by numerous influencing factors that are not, or only very conditionally, controllable. A view of this kind makes analogies to the decision-making reality in organizations in the social economy, especially the garbagecan model with its limited knowledge, imperfect technologies, inconsistent preferences and goals of the organization, and not last but not least, with its fluctuating participation in decision situ ations (Amstutz \& Zängl 2015a/2015b). The primary task of management (or responsible leadership) is to create an opportunity structure in the sense of the garbage-can model, in which decisions relevant to the organization can be made by all.

\section{REFERENCES}

[1] Amstutz, J. \& Zängl, P. (2015a), Was heißt hier eigentlich Management? Entscheidungsarenen und Entscheidungsprozesse in sozialen Dienstleistungsorganis ationen. In: Wüthrich, B. \& Amstutz, J. \& Fritze, A. (Eds.), Soziale Versorgung zukunftsfähig gestalten. Wiesbaden.

[2] Amstutz, J. \& Zängl, P. (2015b), Das Unentscheidbare entscheiden - Skizze eines Forschungsfeldes zum Umgang mit Informationen. In: Bassarak \& Heister \& Leitner \& Mross \& Schneider \& Schubert \& Wendt (Eds.). Kölner Journal. Wissenschaftliches Forum für So-zialwirtschaft und Sozialmanagement 2/2014 1/2015. Baden-Baden: Nomos Verlagsge-sellschaft.

[3] Auer, P. (1986), Kontextualisierung., in: Studium Linguistik 19. S. 22-47.

[4] Strauch B. and Reijmer A. (2018), Soziokratie: Kreisstrukturen als Organisationsprinzip zur Stärkung der Mitverantwortung des Einzelnen, Franz Vahlen Verlang München 
[5] Bauwens, M. (2005), 'A critique of Wilber and Beck's SD-Integral', P/I: Pluralities/Integration, no. 61, $<$ http://www.kheper.net/topics/Wilber/SDi_critique. html> (access ed 2.10.2015)

[6] Beck, D. \& Cowan, C. (1996), Spiral Dynamics: Mastering Values, Leadership, and Change.

[7] Beschorner, T. \& Hajduk, T. (2011), Der ehrbare Kaufmann - Unternehmensverantwortung „light“"? In: CSR MAGAZIN (2011), Nr. 3, S. 6-8

[8] Boaz, Anette, \& Blewett, James (2010), Providing objective, impartial evidence for decision making and public accountability. In I. Shaw, K. Briar-Lawson, J. Orme, \& R. Ruckdeschel (Eds.), The SAGE handbook of social work research. (pp. 37-48). London: SAGE. [Google Scholar]

[9] Bockelbrink, B., Priest, J. \& David, L. (2019), Sociocracy 3.0 - A Practical Guide, ebook.2019.0310.2255 (https://sociocracy30.org/resources/ (accessed 29.3.2019)

[10] Bode, I. (2005), Einbettung und Kontingenz, Wohlfahrtsmärkte und ihre Effekte im Spiegel der neueren Wirtschafts soziologie. In: Zeitschrift für Soziologie, Jg. 34, Heft 4, August 2005, S. 250-269.

[11] Bourdieu, P. (1982), Die feinen Unterschiede. Kritik der gesellschaftlichen Urteilskraft., Frankfurt am Main: Suhrkamp

[12] Brandsen T. (2004), Quasi-Market Governance. An Anatomy of Innovation. Utrecht: Lemma Publishers.

[13] Butters, A. M. (2015), A brief history of Spiral Dynamics, in: Approaching Religion, Vol. 5, No. 2, November 2015 (67-78)

[14] Cohen, M., March, J. \& Olsen, J. (1972), A Garbage Can Model of Organizational Choice, in: Adminstrative Science Quarterly. Vol. 17. No. 1. S. 1-25.

[15] Esser, H. (1990), „Habits“, „Frames“ und „Rational Choice“. Die Reichweite von Theorien der rationalen Wahl (am Beispiel der Erklärung des Befragtenverhaltens), in Zeitschrift für Soziologie. Jg. 19. Heft 4. August 1990, S. 231 247.

[16] Feyerabend, P. (1984), Wis senschaft und Kunst. Frankfurt am Main. Suhrkamp

[17] Fink, F. \& Moeller, M. (2018) Purpose driven Organizations, Sinn - Selbstorganis ation und Agilität. Schäffer-Pöschel, Stuttgart

[18] Foerster, H. v. (1992), Ethics and Second-order Cybernetics, in: Cybernetics \& Human Knowing. Vol 1. No. 1, S. 919.

[19] Galuske, M.(2003), Methoden der Sozialen Arbeit: Eine Einführung (Grundlagentexte Sozialpädagogik/Sozialarbeit) . Weinheim und München: Beltz Juventa

[20] Groenemeyer, A. (Eds.) (1999), Soziale Probleme, soziologische Theorie und moderne Gesellschaften. Opladen: Westdeutscher Verlag

[21] Habermas, J. (1985), Dialektik der Rationalisierung, in: ders.: Die neue Unübersichtlichkeit. Frankfurt a. Main: Suhrkamp

[22] Hamel, G. (2011), First, Let's Fire All the Managers, Harvard Business review; Harvard University, Harvard

[23] https://www.un.org/en/universal-declaration-human-rights/index.html (accessed 29.3.2019)

[24] International Federation of Social Workers (IFSW) and International Association of Schools of Social Work (IASSW) (2012), "Definition of Social Work".

[25] Kindler, H. (2008), Developing Evidence-Based Child Protection Practice. A View from Germany. In: Research on Social Work Practice. 18. Jg., H. 4, S. 319-324

[26] Kotter, J.P. (2011). Leading Change. Wie Sie Ihr Unternehmen in acht Schritten erfolgreich verändern. Vahlen

[27] Kotter, J.P. (2014), Accelerate. Building Strategic Agility for a Faster-Moving World. Harvard Business Review Press

[28] Kreitzer, Mary Jo, Monsen, Karen A. Nandram, Sharda, de Blok Jos (2015), Buurtzorg Nederland: A Global Model of Social Innovation, Change, and Whole-Systems Healing, in: GLOBAL ADVANCES IN HEALTH AND MEDICINE, Volume 4, Number 1 , January 2015, (40 - 44)

[29] Kühl, S. (2016), Laterales Führen. Eine kurze organisationstheoretisch informierte Handreichung zu Macht, Verständigung und Vertrauen. Wiesbaden: Springer VS

[30] Laloux, F. (2014), Reinventing Organizations. A Guide to Creating Organizations. Inspired by the Next Stage of Human Consciousness. Nelson Parker

[31] Lätsch, D. \& Jud, A. (2014), Abklärungsinstrumente sind Kompasse, nicht Autopiloten. Wie wissenschaftlich fundierte Verfahren Fachkräfte bei komplexen Entscheidungssituationen unterstützen können, in: SozialAktuell Nr. $1 / 2014$, S. 24-25.

[32] Le Grand, J. \& Bartlett, W. (1993), The Theory of Quasi-Markets. S. 13-34 in: dies. (Eds.), Quasi-Markets and Social Policy. London: Macmillan. 
[33] Luhmann, N. (1969), Legitimation durch Verfahren. Frankfurt am Main: Suhrkamp

[34] Luhmann, N. (2000), Organisation und Entscheidung. Opladen, Wiesbaden: Westdeutscher Verlag.

[35] Minnig, C. (2019), Kooperation in der Gesundheitsbranche -Trends in der Gesundheitsbrache, Schulte V. u.a. (Hrsg.), in: Entrepreneurship in der Gesundheits wirtschaft", Hanshuber/Hogrefe Bern, 193-177.

[36] Minnig, C. \& Bühler-Rogger, S. (2004), Die Idee der lernenden Organisation als Denkansatz zur Ausgestaltung einer eigenständigeren Corporate Governance-Diskussion im Nonprofit Bereich, in: Voggensperger R. u.a. (Eds.): Gutes besser tun, Bern: Haupt Verlag, Seiten 237-254.

[37] Munro, E. (2005), Improving practice: Child protection as a systems problem, in: Children and Youth Services Review. Volume 27. Issue 4, S. 375-391.

[38] Muoio, A., \& Karmali, F. (2016), The Calculus for Commitment: The Power of Involving the Private Sector in Social Impact Networks. Retrieved from https://ssir.org/articles/entry/involving_private_sector_in_social_impact_network_muoio_monitor_rockefeller

[39] Orton, D., J. \& Weick, K. E. (1990), Loosely Coupled Systems: A Reconceptualization. In Academy of Management Review, Vol. 15: No. 2. S. $203-223$.

[40] Otto, H-U. \& Ziegler, H. (2011), Managerialismus, in: Otto, H.-U. \& Thiersch, H. (Hrsg.), Handbuch Soziale Arbeit. Grundlagen der Sozialarbeit und Sozialpädagogik. 4., völlig neu bearbeitete Auflage. München

[41] Reihlen, M. (2009), Führung in Heterarchien, in: Albers, S. u.a. (Eds.): Management integrierter Wertschöpfungsnetzwerke, Köln: Kölner Wis senschaftsverlag, Seiten 75-111.

[42] Robertson, B.J. (2016), Holacracy. Ein revolutionäres Management-System für eine volatile Welt. Vahlen

[43] Rosling, H., with Rosling, O. \& Rosling Rönnlund A. (2018), Factfulness: Ten Reasons We're Wrong About The World - And Why Things Are Better Than You Think, Flatiron Books, New York.

[44] Sakarya, S., Muzaffer, B., Yildirim-Öktem, Ö., \& Selekler-Göksen, N. (2012), Social alliances: Business and social enterprise collaboration for social transformation. Journal of Business Research, 65, 1710-1720.

[45] Sattelberger, T., Welpe, I. \& Boes, A. (Eds.) (2015), Das demokratische Unternehmen: Neue Arbeits- und Führungskulturen im Zeitalter digitaler Wirtschaft. Haufe-Lexware

[46] Schedler, K. \& Rüegg-Stürm, J. (Eds.), Multirationales Management. Der erfolgreiche Umgang mit widersprüchlichen Anforderungen an die Organisation. Bern: Haupt Verlag

[47] Scherber, S. \& Lang, M. (Eds.) (2015), Agile Führung. Vom agilen Projekt zum agilen Unternehmen. Symposion

[48] Schneider, J. \& Minnig, C. (2011), Management-Modelle und die Führung von NPO - Ein Aufruf zur Modellvielfalt in Lehre und Beratung. In: Fritze, A. \& Maelicke, B. \& Uebelhart, B. (Eds.): Management und Systementwicklung in der Sozialen Arbeit, Baden-Baden: Nomos

[49] Scott, W. R. (1986), Grundlagen der Organisationstheorie. Frankfurt/Main.

[50] Shier, M. L., \& Handy, F. (2016), Cross-Sector Partnerships: Factors Supporting Social Innovation by Nonprofits. Human Service Organizations: Management, Leadership \& Governance, 40(3), 253-266.

[51] Sommerfeld, P. (2003), Zukunftsszenarien Soziale Arbeit. Überlegungen zur Lösung sozialer Probleme. Ein Essay zum zehnjährigen Jubiläum der Unternehmensberatung Viktor Schiess, Unveröffentlichtes Manuskript, Aarau

[52] Staub-Bernasconi, S. (1995), Das fachliche Selbstverständnis Sozialer Arbeit - Wege aus der Bescheidenheit Sozialer Arbeit als Human-Rights-Profession, in: Wendt,W. R. (Hrsg.), Soziale Arbeit im Wandel ihres Selbstverständnisses - Beruf und Identität, Freiburg: Lambertus

[53] Sutherland, J. (2015), Die Scrum-Revolution. Management mit der bahnbrechenden Methode der erfolgreichsten Unternehmen. Campus

[54] Trube, Achim/Wohlfahrt, Norbert (2000). Von der Bürokratie zur Merkatokratie? System- und Steuerungsprobleme eines ökonomisierten Sozialsektors. S. 18-38 in: Karl-Heinz Boeßenecker, A. \& Trube, A. \& Wohlfahrt, N. (Eds.), Privatisierung im Sozialsektor. Münster: Votum.

[55] Uebelhart, B. \& Zängl, P. (2012), Konzeption sozialer Dienstleistungen für die ältere Generation, in: Fretschner, R, Hilbert, J. \& Maelicke, B. (Eds.), Jahrbuch Seniorenwirtschaft 2012, Baden-Baden: Nomos

[56] Uebelhart, B., \& Zängl, P. (Eds.) (2013), Praxisbuch zum Social-Impact-Modell. Baden-Baden: Nomos.

[57] United Nations (2015a), The Millennium Development Goals Report 2015, New York.

[58] United Nations (2015b), Resolution adopted by the General Assembly on 25 September 2015 - Transforming our world: the 2030 Agenda for Sustainable Development, New York

[59] Vermer, A. \& Wenting, B. (2016), Self-Management - How it does work. reed business information, Amsterdam.

[60] Weber, M. (1992), Politik als Beruf (Vortragsmitschrift mit Nachwort von Ralf Dahrendorf). Stuttgart: Reclam 
[61] Wilber, K. (2007), The Integral Vision: A Very Short Introduction to the Revolutionary Integral Approach to Life, God, the Universe, and Everything,

[62] Wolff, S. (2010), Dienstleistungsorganisationen als lose gekoppelte Systeme und Organisierte Anarchien, in: Klatetzki, Thomas (Eds.). Soziale personenbezogene Dienstleistungsorganisationen. Soziologische Perspektiven, Wiesbaden: Springer VS

[63] Zängl, P. (2015), Organisation - Ansätze und Theorien sowie ihre Bedeutung für die Soziale Arbeit. In: Kaegi, U. \& Merten, U. (Eds.): Kooperation in der Sozialen Arbeit. Verlag Barbara Budrich 